\title{
Discourse functions of fronted foci in Italian and Spanish ${ }^{1}$
}

\author{
Lisa Brunetti \\ Universitat Pompeu Fabra, Barcelona
}

\begin{abstract}
This paper analyzes the discourse functions of fronted foci in Italian and Spanish. I aim to show that the peculiarity of fronted focus is that the focus is unambiguously identifiable in the sentence, making the antecedent of the focus variable accessible even (1) when it is not explicitly present in the previous context or not easy to recover, namely in contrastive contexts; (2) when the focus goes against shared knowledge among the interlocutors; and (3) when the focus answers an implicit question or a question located in a rather distant position within the specific discourse.

By means of corpus data, I also intend to show that fronted foci are frequently quantified expressions, expressions of predicative qualification, demonstrative pronouns, and expressions associated with focus sensitive particles. I will explain how these expressions are compatible with the discourse functions of fronted foci.
\end{abstract}

\section{Introduction}

Consider the boldfaced sentences in (1)-(2), taken from a corpus of spontaneous conversations in Spanish (1) and Italian (2). ${ }^{2}$

1. I thank Manuel Leonetti and Victoria Escandell-Vidal for comments, and the anonymous reviewer for useful criticisms. I presented a previous version of this paper at the seminar of the Laboratoire Parole et Langage in Aix-en-Provence: I thank the audience for their comments and questions. I finally thank Tom Rosario for checking my English. The analysis and any possible errors are my full responsibility.

2. Interruptions, repetitions, and other typical imperfections of spontaneous speech have been mostly eliminated for the sake of simplicity and for space reasons. Dots between square brackets indicate the cuts I have made, which can also include speech turns. 
(1) Spanish

UEL: [...] el argumento está muy bien, el Shakespeare este, es un tío [...] listo.

'The plot was very good; that Shakespeare, he is a smart guy'.

ONO: Lo mismo, le pagan de guionista, en Hollywood, una pasta.

'They probably pay him a lot as a script writer in Hollywood.'

UEL: Si se enteran de lo bien que escribe, pues seguro que le fichan.

'If they realized how good he is at writing, they'd hire him no doubt.'

ONO: Seguro que le fichan para Hollywood;

[un OscaR] se lleva, vamos.

an Oscar RFL he.takes really

'They'll hire him in Hollywood, no doubt; he'll get an Oscar, I bet.' [efamdl20]

(2) Italian

a. De Niro [...] sa imporre solo se stesso, come un certo tipo di personaggio, e basta; cioè, in tutti i film che ho visto si comporta e agisce sempre allo stesso modo [...]; cioè, lui, sul set, pù essere solo in quel modo [...]

'De Niro [...] can only impose himself, as a certain type of character, and that's all; that is, in all movies I've seen, he always behaves and acts in the same way [...]; that is, on set he can only be that way [...]'

b. Ed [in QUESTo] sta la sua bravura.

and in that stays the his skill

'And тнат is his strong point.'

[ifamdl01]

These sentences are characterized by a non-canonical word order: the direct object in (1) and the indirect object in (2) occupy a sentence initial, preverbal position instead of their canonical post-verbal position, and the subject occupies a post-verbal position rather than the canonical preverbal one. Furthermore, instead of a descending intonation with main prominence at the end, which is typical of Italian and Spanish canonical sentences, main prominence (indicated with capital letters) falls on the displaced element (delimited by square brackets). In these languages, main prominence - the so-called nuclear accent - is associated with the focus or part of the focus (see Zubizarreta 1998, 1999; Cinque 1993, among others). Therefore, from a pragmatic point of view, these sentences have a focus-background structure.

As observed in the description made by Benincà, Frison \& Salvi (1988 [2001]) and Salvi (1988) (among others) for Italian, these constructions are further characterized syntactically by the absence of a resumptive clitic pronoun inside the clause, which 
distinguishes them from the so-called 'Clitic Left Dislocation' (cf. (3a) vs. (3b)). ${ }^{3}$ Still, unlike a Clitic Left Dislocation, not more than one element can be fronted (see (4)). ${ }^{4}$

(3) Italian
a. [Tuo FRATELLO] ho visto. your brother I.have seen '(It's) your brother (who) I have seen.'
b. Tuo fratello, l'ho visto.
your brother him.CL I.have seen
'(As for) your brother, I have seen him.'

(4) Italian

$$
\begin{aligned}
& \text { *[Mio FIGLIO], [ Una POESIA }] \text { ha scritto. } \\
& \text { my son a poem has written }
\end{aligned}
$$

Instead, these constructions have some characteristics in common with wh-interrogatives; i.e., the verb tends to be adjacent to the displaced element (cf. (5a) and (5b)). ${ }^{5}$

(5) Italian
a. ${ }^{\star}$ Che cosa Giorgio porta?
that what Giorgio brings

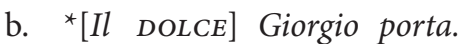
the cake Giorgio brings

The Spanish construction has the same properties. The following examples from Zubizarreta (1999) show that the fronted element is not resumed by a clitic inside the clause (6a); it has to be adjacent to the verb (6b); and no more than one element can be fronted (6c).

(6) Spanish
a. [El DIARIO $] \quad\left({ }^{*}\right.$ lo) compró Pedro.
the newspaper it.CL bought Pedro
b. * [El DIARIO $]$ Pedro compró. the newspaper Pedro bought
c. *[La manzANA $],[$ a $E V A]$, le dio Adán. the apple to Eve to.her.CL gave Adam

3. Benincà calls this construction 'topicalization', but as noted by Salvi (1988), the term is inappropriate and misleading: the displaced element does not have a topic (that is, thematic) function, but rather it is the focus of the sentence.

4. In effect, multiple fronting seems to be possible in certain cases. In Brunetti (2004:91-92) I analyze them as cases of incorporation of two foci into one.

5. In Brunetti (2004:39-40), this tendency is related to the discourse-linking properties of the fronted element. 
Zubizarreta also points out that the fronted element can be separated from its sentence by several intermediate sentences (7a). The same is true for Italian (7b): although pragmatically rather odd, the sentence is syntactically adequate.

(7) a. Spanish

[MANZANAS] me aseguran que dijo María que compró Pedro. apples me.CL they.ensure that said María that bought Pedro 'It's apples that they ensure that María said that Pedro bought.'

b. Italian

[MELE] mi confermano che abbia detto Maria che Pietro apples to.me.CL they.confirm that has said Maria that Pietro ha comprato.

has bought

'It's apples that they confirm that Maria said that Pedro bought.'

Finally, the fronted element in both languages is subject to island constraints: it cannot be grammatically related to a position inside a relative clause (8), an adverbial clause (9), or a subject clause (10):

(8) a. Spanish

* [A PEDRo] conocemos la mujer que traicionó.

to Pedro we.know thewoman who betrayed

b. Italian

${ }^{*}[$ PAOLO $]$ conosciamo la donna che tradi.

Paolo we-know the woman who betrayed

(9) a. Spanish

* [A PEDRO] terminemos la tarea antes de llamar.

to Pedro we.finish the assignment before to call

b. Italian

*[PAOLO] finiamo il compito prima di chiamare.

Paolo we.finish the assignment before to call

(10) a. Spanish

* [A PEDRO] sorprendió a todo el mundo que María haya invitado. to Pedro amazed to all the world that María has invited

b. Italian

*[PAOLO] ha sorpreso tutti che Maria abbia invitato.

Paolo has amazed everybody that Maria has invited

Which exact position the fronted element occupies lies beyond the scope of this article. The word 'fronting' itself is a descriptive term and does not mean that the focused element has been moved syntactically. Given the syntactic properties presented above, most accounts propose that the fronted focus occupies an A' position (see Rizzi 
1997, a.o.); however, a different account has been proposed where the focused element stays inside the clause and the background moves to a right dislocated position (see Samek-Lodovici 2006, this volume). The pragmatic analysis of fronted foci that I am presenting in the following paragraph is compatible with both analyses. As we will see, what is crucial for pragmatic purposes is that the focus constituent be distinguishable from the background constituent.

\section{The discourse functions of fronted focus constructions}

The focus-background order is quite rare in Italian and Spanish. Pragmatically speaking, the most neutral configuration is a topic-comment one, where the topic is a referential element either given in the discourse or as being part of the interlocutors' shared knowledge, and expresses what the sentence is about, while the comment is the information provided by the sentence about the topic. In the most unmarked case, the topic is represented by the preverbal subject and the comment coincides with the predicate (the verb followed by the other arguments, cf. (11a)). Contrarily, in a focus-background configuration, the informative part - the left peripheral focus - is (generally) a referential element, typically represented by an argument of the verb, while the information already shared by the interlocutors - the background - coincides with the predicate and the remaining arguments (cf. (11b)).

(11) Italian
a. $[\text { Paolo }]_{\text {Topic }}$ [ha dato un bacio a MARIA $]_{\text {Comment }}$ Paolo has given a kiss to Maria
'Paolo, he gave a kiss to MARIA.'

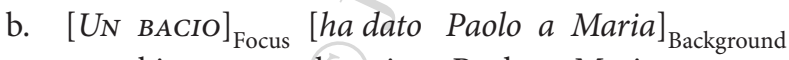 a kiss has given Paolo to Maria
'Paolo gave Maria a KIss.'

Given that in this paper I analyze sentences with a focus-background order, in the same group I will include those sentences which, although syntactically canonical (in the sense that they display a subject-verb-object (SVO) order), are prosodically noncanonical, because the preverbal subject bears main prominence (cf. io 'I' in the Italian corpus example below).

(12) Italian

A: "[...] forse più che egoista sono individualista".

'Rather than selfish, I would say I am an individualist.'

B: Ho detto: "No, [Io] sono individualista, tu invece sei egoísta". have said no I am individualist you instead are selfish "And I said: "No, I am an individualist, you are just selfish". [ifamcv21] 
Both Benincà, Frison \& Salvi (1988 [2001]: 150) and Zubizarreta (1999:4240) define the pragmatic function of a fronted focus as the denial of an explicit or implicit part of the context in which it is inserted. In other words, a fronted focus provides a piece of information that contrasts with (or corrects) a previous one in the context. I argue that contrast can also occur between the information provided by the fronted focus and an implicitly assumed belief, given the interlocutors' shared knowledge of the world. In that case, the information provided by the focus is felt to be unexpected. ${ }^{6}$ Finally, as already observed in Brunetti (2004), the fronted focus can simply answer a question. The question, however, has either to be implicit or not present in the immediately preceding discourse, as we will see below.

In Brunetti (2008, in press) I claim that the pragmatic function of a fronted focus construction is related to the fact that the background in post-focal position is a tail in the sense of Vallduví (1992, 2002). I assume a tail to be background material which requires an antecedent in the context, and argue that the antecedent must be a shared belief among the interlocutors. In this paper, I put forward that such a definition - reformulated within an Alternative Semantics framework - can also apply to pre-focal material. In fact, I argue that it is possible to explain the difference between pre- and post-focal material without assuming that they are two inherently different background types. The difference between them would then be due to the fact that pre-focal material is not unambiguously interpreted as background, while post-focal material is.

According to the Alternative Semantics framework (Rooth 1985, 1992), a sentence containing a focus other than its semantic value has an additional focus semantic value', which is a set of propositions obtainable from the semantic value of the sentence by substituting the position which corresponds to the focus. For instance, in a sentence like (13a) where $a$ book is the focus, the set of propositions is of the kind displayed in (13b).

(13) a. I gave а воок to John.

b. Focus semantic value:

\{I gave a book to John, I gave a cd to John, I gave a cookie to John, etc.

Obviously, not all potential alternatives of the focus semantic value are relevant in the context in which the sentence is uttered. In fact, Rooth proposes that the focus value has to be restricted by a pragmatic process. Rooth's idea is that focus interpretation introduces a free variable whose antecedent is a discourse object which is either a subset or an element of the focus semantic value. The antecedent is fixed by the context and determines what pragmatic function the focus has: contrast, correction, answering a question, etc. Consider for instance (13). The antecedent of the focus variable must be an element or a subset of the focus value I gave $x$ to John. Therefore, the antecedent can

6. For the idea that fronted focus conveys unexpected information see also Vallduví (1992) for Catalan and Matić (2003) for Albanian, Serbo-Croat and Modern Greek. 
be a sentence of the type in (14a) - in which case (13a) will be in contrast with it - or it can be a wh-question of the type in (14b) - in which case (13a) has the function of answering that question.

(14) a. You gave John a magazine.

b. What did you give to John?

A fronted focus is expected to behave like any other focus. Nevertheless, a fronted focus has an additional property with respect to other foci, which has to do with the way Italian and Spanish - as well as other European languages - mark the focus domain linguistically (more precisely, prosodically). In these languages, focus interpretation projects from the focused element, bearing the nuclear accent up through the main syntactic branching of the sentence, which in these languages is to the left (cf. Cinque 1993; Reinhart 1995, 2006; Zubizarreta 1998). Focus extension is therefore ambiguous if the constituent bearing the nuclear accent is embedded in larger constituents along the main syntactic branching. The most ambiguous case is when the nuclear accent is placed on the most embedded element of the sentence. For instance, the extension of the focus in (15B), with the nuclear accent on the most embedded element Maria, may be any of the extensions given in square brackets, as shown by the fact that the sentence may answer any of the questions in (15).

(15) Italian
A: A chi ha dato un bacio, Paolo?
'Who did Paolo kiss?'
A': Che cosa ha fatto, Paolo?
'What did Paolo do?'
A": Che cosa è successo?
'What happened?'
B: $\quad\left[\text { Paolo }\left[\text { ha dato un bacio }[\text { a } \text { MARIA }]_{\text {Focus }}\right]_{\text {Focus }}\right]_{\text {Focus }}$
Paolo has given a kiss to Maria
'Paolo gave a kiss to Maria.'

It is clear that when a sentence has a narrow focus which is low, the sentence can be misinterpreted as having a wider focus or as being fully focused, and the context must help disambiguating the information structure. On the contrary, if the narrow focus is high and precedes the background, given that focus projects to the left, the post-focal background cannot be interpreted by any means as part of the focus. In other words, since the right edge of the focus is marked, the linguistic material following it cannot be but background. This means that a focus-before-background order in a sentence is not ambiguous. The extension of the focus does not have to be recovered from the context, like in (15). The focus is identifiable by means of the sentence alone.

Note that given Rooth's definition of the focus semantic value and of the antecedent of the focus variable (cf. (13) and related discussion), the narrower the focus, the more constrained and therefore semantically defined is the antecedent. For 
instance in (15B), if the focus is a Maria, the antecedent will be of the type Paolo gave a kiss to $x$, whereas if the focus is the whole verb phrase, the antecedent is of the less specific type Paolo R-ed. Consequently, the antecedent of the variable introduced by a narrow focus is harder to find in the context than that of a variable introduced by a wide focus, because the context has to be more specific. As a result, when the focus extension is ambiguous, a listener will tend to interpret the focus as wide by default, unless an explicit and easily accessible antecedent for the narrow focus variable is provided by the context. A fronted focus, however, is not ambiguous, so the listener cannot interpret it as wide by any means. The listener is then forced to look for an antecedent of the narrow focus variable, even when the context does not seem to contain it at all. In case of a context that does not provide it explicitly, the listener will make inferences in order to retrieve the antecedent implicitly.

The idea that the peculiarity of a fronted focus is its unambiguous identification is compatible with an idea concerning the interaction between syntax and information structure presented in recent work by Neeleman \& van de Koop (2007). Assuming that the focus moves to the left periphery, they propose that focus movement occurs in order to facilitate a transparent mapping between syntax and information structure. In fact, by displacing the focused element to the left, the focus-background partition of the sentence is perfectly reflected in the constituent structure, because focus and background are represented by two continuous constituents:

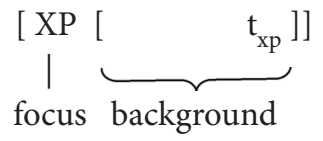

In my analysis, the syntax-information structure transparent mapping - whether triggered by focus movement or by other syntactic operations, such as right dislocation of the background - makes the listener understand that, independently from any cues from the context, the focus of the sentence is narrow and corresponds to the fronted element. The unambiguous characterization of the focus extension makes a fronted focus construction a better answer to a question whenever the question is implicit or not salient. The content of the implicit question can in fact be recovered from the focus semantic value of the answer, and the non-salient question can be retrieved by matching its content with that of the focus semantic value of the answer. For the same reason, a fronted focus typically occurs in contrastive/corrective contexts. Unlike question-answer pairs, contrasting sentences are not tied to each other by a congruence requirement. Which part of the previous discourse a speaker wants to contrast (or correct) is not necessarily predictable from the context. The possibility to identify the focus independently from the context helps the listener find the antecedent of the variable introduced by the focus which is contrasted with the sentence. Finally, the unambiguous interpretation of the fronted focus is required when the sentence contrasts an implicit belief that is assumed by the interlocutors given their 
shared knowledge of the world. The focus value tells the listener what the form of the antecedent is, so the listener can recover that implicit belief.

The analysis just presented can be compared with Prince's (1999) analysis of fronted foci in Yinglish, a variety of English spoken by Jewish communities in the US with a Yiddish linguistic background. Yinglish has inherited from Yiddish the possibility to front the focus - a construction generally not accepted in standard English. Prince argues that a fronted focus sentence is possible if the information in the background - what she calls the 'open proposition', namely the proposition formed by substituting the focused element with a variable - is already known to or at least plausibly inferable by the listener. For instance in (17), the fronted focus is acceptable because it is considered to be a well known fact in the Yiddish community that sons ask parents to buy them things, so the open proposition 'my son wants $\mathrm{x}$ ' is already part of the listener's knowledge store.

(17) A: Hello, Mrs. Goldberg. How's everything? How's your son?

B: Oy, don't ask. [A sPORTSCAR] he wants - that's all I was missing.

Within an Alternative Semantics framework, the definition of background as an open proposition can be assigned to background in any construction with narrow focus (cf. 13). As I have explained, a fronted focus construction additionally implies that the narrow focus is unambiguously identified, because focus marking (by means of the nuclear accent) projects to the left (which is true also for English, cf. Reinhart 1995, 2006). Thus, in (17), it is not simply the case that the fronted focus is used because the proposition 'my son wants $\mathrm{x}$ ' is already part of the listener's knowledge store - which is expected if that part is the background. Rather, the fronted focus is used because the sentence does not directly answer speaker A's question, so the antecedent of the focus variable is not directly recoverable from the question but has to be inferred. With a fronted focus construction, the listener knows what the focus semantic value is and hence what must be the antecedent for the focus variable. The listener infers that a proposition of the type 'my son wants $x$ ' is present in the common ground. More precisely, I would like to suggest that the interlocutors share an implicit question of the type 'What does your son want?' That implicit question, which Jewish mothers ask each other when they talk (and complain) about their sons, constitutes the antecedent of the focus variable.

A construction similar to a fronted focus but much more constrained with respect to the antecedent is a cleft. Like a fronted focus construction, a cleft has an initial narrow focus (the clefted element) followed by background material. Nevertheless, as already observed by Benincà, Frison \& Salvi (1988 [2001]), clefts occur in a smaller number of contexts: while a fronted focus is possible in all contexts in which a cleft is possible, the opposite is not true. An anonymous reviewer has made an analogous observation for the data presented in this paper, noting that some fronted focus sentences could be replaced by the corresponding cleft, while some others could not. The reviewer suggests that this fact be an indication that we are dealing with two different 
fronted focus constructions. I argue instead that a uniform analysis can be maintained. Benincà, Frison \& Salvi observe that the displaced element of a cleft cannot be a quantifier (cf. (18)). ${ }^{7}$ Also, a cleft cannot be used as an answer to a negative polarity question such as (19):

(18) Italian

a. A: Hai fatto qualcosa?

'Did you do anything?'

B: [Tutтo] ho fatto. / ' ${ }^{*}$ титто che ho fatto. everything I.have done is everything that I.have done 'I did EVERYTHING.' 'It's EVERYTHING that I did.'

b. A: Tu vuoi invitare Giorgio.

'You want to invite Giorgio.'

B: [NESSUNo] voglio invitare. ${ }^{*} E$ ' NESSUNO che voglio invitare. nobody I.want to.invite is nobody that I.want to.invite 'I want to invite NOBODY.' 'It's NOBODY that I want to invite.'

(19) Italian

A: Ti a detto nessuno che dovevo partire?

'Did anybody tell you that I had to leave?'

B: [FrANCO] me l'ha detto ${ }^{*} E^{\prime}$ Franco che me l'ha detto.

Franco to.me.CL it.CL has said is Franco that to.me.CL it.CL has said 'Franco told me that.' It's Franco who told me that.'

These data suggest that the antecedent of the clefted element is a (semantically determined) existential presupposition. For instance in (19), the cleft triggers the presupposition that someone exists who told speaker B about speaker A's departure. As Benincà, Frison and Salvi explain, the question containing the negative polarity item does not trigger the same presupposition of existence, so it cannot provide an antecedent for the focus of the cleft. Focus fronting, on the contrary, simply implies that there is a proposition in the previous discourse (explicitly or implicitly given) or in the interlocutors shared knowledge, which can serve as antecedent for the focus variable. ${ }^{8}$ The proposition can either be an element of the focus semantic value (e.g., cases of contrast/correction, unexpected information), or it can be a sub-set of the focus semantic value (e.g., a question). In any case, it does not need to presuppose that someone exists who 'told the speaker about it'. A fronted focus construction may in

7. Although the difference is not clear-cut. See Brunetti (2004:70-72) for examples where a cleft with a quantifier is acceptable.

8. There is ample discussion in the literature on the difference between semantically vs. pragmatically determined presupposition. See for instance the debate on the Special Issue of Theoretical Linguistics (2004), where different authors comment on Geurts \& van der Sandt's paper 'Focus interpretation'. 
some contexts require an antecedent that is compatible with the presupposition triggered by a cleft. For instance, a presupposition of existence that someone (else) has the same property as the fronted focus is generally compatible with contrastive contexts. Indeed, in contrastive contexts a cleft can typically replace the fronting. In other contexts, however, the implication triggered by the fronted focus may not be compatible with the semantic presupposition of the cleft, which therefore cannot be used there.

In the following paragraphs, I present the two speech corpora from which my data has been retrieved, and provide corpus examples of the different pragmatic uses of fronted foci. In Section 4, by means of my data, I will also present certain linguistic properties of fronted foci. We will see that some linguistic expressions tend to occur more often than others in a fronted position, and that their frequency is related to the discourse functions of fronted foci.

\section{The data}

The data I will discuss is taken from two oral corpora. The first corpus is the C-ORAL ROM (Cresti \& Moneglia 2005), which consists of monologues, dialogues, and conversations with varying degrees of spontaneity in different Romance languages. I have only considered a selection of dialogues and conversations with a rather high level of spontaneity in Italian and Spanish. For Italian, I have considered:

- 10 conversations and 11 dialogues that took place in a family/private environment,

- 3 conversations and 3 dialogues that took place in a public environment,

- 3 private telephone conversations,

- 1 conversation on the radio.

The total for Italian is 45,500 words of about five and a half hour of speech. For Spanish, I have considered:

- 10 conversations and 21 dialogues that took place in a family/private environment,

- 9 dialogues that took place in a public environment.

The total is 59,800 words of about five hours of speech. The reasons that led me to exclude some recordings were either the low quality of the sound, which affected the detection of a focal accent in the left periphery, or speakers using an excessively marked language variety, either geographically or because of the age of the speakers. In other words, I tried to gather a rather uniform set of data from a corpus rather characterized by a large variation of registers and styles. The examples taken from this corpus are labeled with a sequence of letters followed by a number. The first letter indicates the language (i for Italian, e for Spanish). The next set of letters indicates whether the speech takes place in a family/private environment (fam) or in a public environment (pub), and whether it is a dialogue ( $\mathrm{dl}$ ) or a conversation (cv). The number identifies the specific recording. 
The other corpus is the Nocando corpus, which I have compiled myself. ${ }^{9}$ This corpus consists of oral narrations in Italian, Spanish, Catalan, English and German. The speech data were obtained by asking native-speakers to narrate a story based on the pictures of three textless books by Mercer Mayer. Mayer's books had been previously used in linguistic research to elicit child and adult oral narrations (see Berman \& Slobin 1994; Strömqvist \& Verhoven 2004). They describe the adventures of a boy and his pet frog. Each recorded story lasts between two and nine minutes approximately, depending on the speaker. I examined the narrations of fifteen Italian speakers and eight Spanish speakers, with a total of about 26,800 words for Italian and about 17,200 words for Spanish. The examples taken from this corpus are indicated with iNoc (for Italian) and eNoc (for Spanish), followed by the narrator's name.

The number of fronted foci found in the Italian corpus are 60, and in the Spanish corpus 28. In addition, in the Spanish corpus I found 48 cases of polarity (fronted) focus which I will discuss separately. If we exclude those cases, the phenomenon is much less common in Spanish than in Italian. In the following paragraphs, I will present some of these data in order to show more clearly the different discourse functions of fronted foci.

\subsection{Examples of contrast or correction}

The Italian example in (12), repeated below, is a typical case of fronted focus expressing contrast. The speaker is talking about a conversation she had been engaged in with a third person. She is quoting her interlocutor's words (12a) and her own reply (12b). The interlocutor had said that he is an individualist. The speaker had replied that it is her (and not him), who is an individualist. The proposition the speaker challenges is explicitly expressed by the interlocutor's utterance.

(12) Italian

a. "[...] forse più che egoista sono individualista".

'Rather than selfish, I would say I am an individualist.'

b. Ho detto: "No, [Io] sono individualista, tu invece sei egoísta." have said no I am individualist you instead are selfish 'And I said: "No, I am an individualist, you are just selfish". [ifamcv21]

Note that the fronted focus sentence is preceded by No, .... The negative particle indicates that the speaker denies the truth of the previous sentence, and the subsequent fronted focus sentence makes it clear where the falsity lies. What the speaker denies

9. The corpus was created within the project Nocando, Construcciones no-canónical en el discurso oral: estudio transversal y compartivo, Universitat Pompeu Fabra, Barcelona (principal investigator Enric Vallduví), funded by the Spanish Secretaria de Estado de Universidades e Investigación del Ministerio de Educación y Ciencia, n. I+D HUM2004-04463. 
is the identity of the individual with the property of being individualist. The possibility to unambiguously identify the focus makes it easier to interpret the sentence as a clarification of what part of the previous sentence has to be corrected. Still, a low focus like (20) is equally acceptable in this context, because the initial negation gives a cue of the contrasting function of the subsequent sentence.

(20) No, individualista sono Io, tu invece sei egoista. no individualist am I you instead are selfish 'No, I am individualist, you are just selfish.'

The example below shows a case where the contrasted proposition can implicitly be derived from the context. Some friends are talking about the Italian actor Massimo Troisi. Previously in the conversation, various films he starred in were discussed. Some people had made positive comments on such movies. GIA then introduces a new film, Il postino. With the subsequent utterance, containing a demonstrative fronted focus referring to Il postino, GIA intends to compare that film with the other films already introduced in the conversation. More precisely, he implies that his appreciation of Il postino contrasts with previous statements of appreciation of different movies made by other speakers.

(21) Italian

GIA: "Il postino”... C'era Troisi?

“The mailman"... Was Troisi (starring) in it?"

FAB: $\quad$ Si.

'Yes.'

GIA: Vedi: [QuelLo] mi è piaciutodi Troisi.

you.see that to.me.CL is pleased of Troisi

'See, it is тнAт film of Troisi's that I liked.'

[ifamcv12]

Note that in this example, if the fronting did not occur (see (22)), the focus of the sentence would likely be held to be the whole verb phrase (mi è piaciuto quello) because the verb piacere 'to be pleasing' is not explicitly given in previous discourse. The fronting makes it clear that the focus is just quello 'that', so it forces the listener to look for an antecedent of the type 'I liked x', and consequently to contrast that (movie) with other movies.

(22) Italian

$\begin{array}{llll}\text { GIA: Vedi, } m i \quad \text { e piaciuto QUELLO, } & \text { di Troisi. } \\ \text { you.see to.me.CL is pleased that } & \text { of Troisi }\end{array}$

'See, I liked THAT one of Troisi's.'

An example of correction is given in (23). The speaker is correcting a statement she made earlier in the conversation. She talked about the special events that an Indian 
restaurant offers on different days of the week, and said that on Saturday night the event that will take place is horoscope reading. Then the conversation focused on horoscope reading, and after 24 exchanges, the speaker corrects that former statement by saying that it is the fortune teller who is there on Saturday, not horoscope reading. The fronted focus allows the listener to easily recover the proposition that has to be corrected which was uttered far back in the discourse.

(23) Italian

No, scusami, [la CARTOMANTE $]$ cèe, i'sabato sera.

no excuse.me the fortune.teller there is the Saturday night

'No, sorry, on Saturday night there is a fortune teller.'

[ifamcv26]

Another example of correction is given below, once again in Italian. The focus is a temporal noun phrase: giovedi 'Thursday'. FRA corrects PAO's (in this case, explicit) assumption that FRA has already started working at the library.

(24) Italian

PAO: Ma te oggi c' ha' fatto? Se' stata qui? [...] Ah, t'ha cominciato alla Nazionale!

'But what did you do today? Were you here? [...] Ah, you started in the State library!'

FRA: Giovedi, [GIOVEDì] comincio.

Thursday Thursday I.start

'It's on Thursday, it's on Thursday that I'll start.'

[ifamdl12]

PAO wants to know what FRA did on that day, and after asking a direct question (Ma te oggi c'ha' fatto? 'But what did you do today?'), she guesses an answer by saying that FRA started to work at the State library. FRA is expected to say what she did on that day, and particularly to confirm whether she started to work at the library or not. Imagine now that FRA's reply was (25), with a low focus.

(25) Italian

FRA: Comincio GIOVEDì.

I.start Thursday

'I'll start on Thursday'

The sentence would be interpreted as fully focused, because a focus value like 'I start on day x' is not given in prior discourse. But a fully focused sentence would sound pragmatically odd, because the information 'I'm starting to work on Thursday' is not an answer to 'What did you do today?'. (25) may be interpreted as narrow-focused (and therefore be more coherent) if it is preceded by a negation (No, comincio giovedi). In fact, the negation denies the correctness of PAO's conjecture, so the subsequent 
sentence is understood as a clarification of where the mistake lies. In (24), thanks to the fronting, the focus is unambiguously 'Thursday', so PAO knows that she has to look for an antecedent of the type 'FRA starts working on day x', and hence she can make the inference that FRA's reply is intended to oppose 'Thursday' against 'today', namely that FRA is not confirming her conjecture and is further specifying where the mistake lies.

\subsection{Examples of unexpected information}

The literature recognizes that the pragmatic function of a fronted focus is to contrast its value with another value present in the context. We have seen that a fronted focus is indeed useful in contrastive contexts because it helps to recognize the contrasting function of the focus (cf. for instance (24)). However, in some cases the contrastive effect may be easily recognizable even with a low focus (cf. (12)). A contrastive interpretation is then not necessarily tied to the fronted position of the focus. On the other hand, in the set of contexts that I am going to present, contrast is not visible unless the focus is fronted. In these contexts, the focus contrasts a belief shared among the interlocutors, taken from their shared knowledge of the world (knowledge of how things are, of how a certain event occurs, of the properties that a certain entity has, etc.). Since the antecedent of the focus variable cannot be found in the discourse context, if the focus is not fronted, the listener cannot easily identify its antecedent. If the focus is fronted, the antecedent is identifiable independently from the context, so if not present in the context, the listener will look for it elsewhere, and this precisely in the interlocutors' common ground.

Given that the fronted focus contrasts with the knowledge shared by the interlocutors, the information it provides is felt to be unexpected. ${ }^{10}$ Consider again (2), repeated below. In the preceding discourse, MIC says that any role De Niro plays is strongly affected by his personality, that De Niro basically always plays himself. Given that acting is a skill where a person pretends to be someone else, MIC's observation may lead the listener to conclude that De Niro is not a good actor. This fact justifies the fronted focus: contrary to what the listener is led to infer, it is precisely the fact that De Niro always represents the same character that makes him a good actor. The focus in questo 'in this' refers to the fact that De Niro always plays the same character in his movies.

10. Matić (2003) unifies the notions of 'contrast' and 'unexpectedness' by defining contrast as going against the listener's expectations. The two effects can be set apart if we take into account where the antecedent is found: either in previous discourse (contrast) or in the shared world knowledge (unexpectedness). There are also some midway cases though: when the information of previous discourse has become a new piece of shared knowledge or belief among the interlocutors, and the fronted focus sentence goes against the expectations deriving from it. See examples (29) and (42). 
(2) Italian

a. De Niro [...] sa imporre solo se stesso, come un certo tipo di personaggio, e basta; cioè, in tutti i film che ho visto si comporta e agisce sempre allo stesso modo [...]; cioè, lui, sul set, può essere solo in quel modo [...]

'De Niro [...] can only impose himself, as a certain type of character, and that's all; that is, in all movies I've seen, he always behaves and acts in the same way $[\ldots]$; that is, on set he can only be that way $[. . .]^{\prime}$

b. ed [in QUESTO] sta la sua bravura.

and in that stays the his skill

'and THAT is his strong point.'

[ifamdl01]

If the focus was low (see (26)), no effect of unexpected information would be conveyed by the sentence. In fact, the focus value 'his strong point is $\mathrm{x}$ ' does not have an antecedent in the discourse, so the sentence would likely be interpreted as fully focused.

\section{(26) Italian}

E la sua bravura sta in QUESTO.

and the his skill stays in that

'And his strong point is THAT.'

With focus fronting, on the contrary, the focus value necessarily is 'his strong point is $\mathrm{x}$, so if the context does not provide an antecedent of that sort, the listener will look for it among the beliefs shared by the interlocutors (in 2, such a belief is 'His strong point as an actor is to be able to perform many different characters'). The fact that the antecedent is part of the interlocutors' shared knowledge gives rise to unexpectedness.

Further examples of unexpected information will be given in Section 4, where different types of focus-fronted expressions are presented.

\subsection{Examples of answers to questions}

It is generally assumed in the literature (cf. Benincà, Frison \& Salvi 1988 [2001]; Rizzi 1997; Zubizarreta 1998, 1999, etc.) that a fronted focus cannot answer a wh-question. The explanation given is that a fronted focus is inherently contrastive. In Brunetti $(2004,2008)$ I provide some evidence that the contrastive interpretation of a fronted focus is not obligatory. As the data below furthermore show, the problem is not that a fronted focus answers a question, but that it answers an immediately preceding question. If the question is far back in the discourse or is implicit, it is not only possible but even necessary that the answer have a fronted focus. In fact, the fronting helps to find the antecedent of the focus variable (the question) by providing the exact extension of the focus. 
Consider (27). The speaker wants to relate to her friends a funny thing that somebody said on TV. She starts her story by stating that she heard someone saying a funny thing, but she does not recall who this person was. She hesitates, trying to remember, and eventually utters the fronted focus sentence where she says who she thinks he was.

(27) Italian

a. L'ho sentito alla televisione da uno... ora non mi ricordo come si chiama... 'nsomma...

'I heard it said on TV by a guy... now I don't remember his name... anyway...'

b. [un politico dei DIEsse] mi sembra che fosse.

a politician of.the DS to.me.CL seems that he.was

'I think he was a politician of the DS party'.

[ifamcv23]

The construction is licensed by the fact that the listeners share with the speaker an implicit question about the identity of the person. The question is induced by the speaker's words which precede the sentence: the listeners understand that the speaker wants to say who this person is, but is hesitating because she cannot remember. Focus fronting is also favored by the fact that the semantic content of the non-focused part is minimal: the content of the implicit question representing the antecedent is minimal as well, namely, the question simply asks who that person is, and therefore it is easy to recover.

The Italian example in (28) shows a fronted focus sentence that answers a question uttered far back in the discourse. The focus is the nominal expression quaranta bianchi 'forty whites'. The speaker (WOM, a goldsmith's employee) is about to leave the goldsmith's atelier to go buy some material. The antecedent for the focus variable is the question that the woman asks at the beginning of the discourse segment (fammi vedere quanti ne servono 'let me see how many we need'). Five exchanges follow between the woman and the goldsmith (AND), after which she answers her own former question with a fronted focus sentence. The fronting allows the listener to interpret the sentence as the answer to that previously asked question.

(28) Italian

WOM: Okay, se lui ce li ha sfusi... Fammi vedere quanti ne servono.

'Ok, if he has them unpacked... Let me see how many we need.'

AND: $\quad S i$.

'Ok.'

WOM: Ma non credo che ce li ha sfusi.

'But I doubt he has them unpacked.'

AND: Questo grigio, dove l'hai preso?

'This grey one, where did you take it from?'

WOM: Dieci, dieci... mah, un mi ricordo, comunque sento. [...]

'Ten, ten... er, I don't remember; in any case I'll ask.' 
WOM: a. Io sento dove vado, intanto dal Celerini, e poi dipende dove devo andare.

'I'll ask wherever I go: first at the Celerini's, and then, depending on the place I have to go.'

b. Dieci, venti, trenta, quaranta... [quarantaBIANCHI]

ten twenty thirty forty forty whites

mi servono, allincirca.

to.me.CL are.needed at.the about

'Ten, twenty, thirty, forty... it's FORTY WHITE ones that I need, roughly.'

[ifamcv28]

In (29) the fronted focus is a verb phrase: ir a nadar 'to go swimming. BEA starts that conversation segment by commenting on the importance of having leisure activities. The two speakers then start talking about what activity they could do after their aerobics class ends. After considering prospective aerobic classes available in different gyms, BEA concludes that she would like to go swimming. Since the discussion had only focused on aerobics until then, BEA's statement is coherent in the discourse only if we interpret it as referring to the general topic of finding a leisure activity, and in particular as an answer to an implicit question of the type 'What leisure activity would you like to do when the aerobics class ends?', which is recoverable from the part of conversation reported in (29). ${ }^{11}$

(29) Spanish

BEA: $\quad$ No está mal tener actividades de ocio [...]

'It's not bad to have leisure activities.'

VIT: Sí, como el aerobic, por ejemplo.

'yes, like aerobics, for instance.'

BEA: a. Que se nos acaba. Tendremos que buscarnos otra cosa, no? [...] 'which is about to end. We'll have to look for something else, don't you think?' [...]

b. Sí que nos tendremos que buscar algún sitio... a mí sí que me apetece seguir...

'We definitely should look for some place... I do want to continue...'

c. [Ir a NADAR] me gustaría.

to.go to swim to.me.CL would.please

'I would like to go swimming.'

11. Alternatively, we could interpret the antecedent as 'I would like to go to aerobics class', and the fronted focus sentence would go against the expectations created by the previous discourse (see previous footnote). 
Finally, the sole case in the two corpora where a fronted focus sentence answers an explicit question is given below. The example is in Spanish and the focus is la energía solar 'solar energy'.

(30) Spanish

ALM: Y ahora mismo, cuál es la que menos oposición tiene por parte de la gente?

'And right now, which is the one that encounters less opposition by the people?'

JAV: Yo no sé cuál será, probablemente[la energía sOLAR] I not know which will.be probably the energy solar será la que menosoposición tenga.

will-be the.one that less opposition has

'I don't know which one; probably solar ENERGY will encounter less opposition.'

[epubdl03]

The reason for a full fronted focus answer is not clear to me. I suggest that it depends on the fact that JAV reformulates ALM's question before uttering his answer, and the reformulated question is elliptical (la que menos oposición tiene 'the one that encounters less opposition' is missing). It may be the case that the elliptical question legitimates a full answer rather than just a fragment answer (la energía solar).

\subsubsection{Request of confirmation}

A sub-set of fronted focus constructions with an implicit question as antecedent are those that ask for confirmation about some piece of information expressed by the focus. The sentence can either be a declarative followed by a tag question (...no?, see (31)) or a yes/no question (see (32)). The implicit (wh-)question is precisely the one concerning the piece of information the speaker is not sure about. In the Spanish example in (31), NIV and her husband are going to rebuild part of their apartment. RIC asks for confirmation that the part they are going to renovate is the kitchen. Since NIV has been talking about the building work (la obra), and since the interlocutors know that this work is being done in NIV's apartment, it is easy for the listener to retrieve from the sentence with fronted focus cocina 'kitchen' an implicit question of the type: 'What rooms of your apartment are you going to remake?'.

(31) Spanish

NIV: [...] y el sábado viendo [...] cosas para la obra [...]

'And Saturday looking at [...] things for the building work.'

TER: La vais a hacer ya, por fin? [...]

'So you are going to do it, in the end?'

NIV: Sí, ya lo tenemos.

'Yes, we are on it already'. 


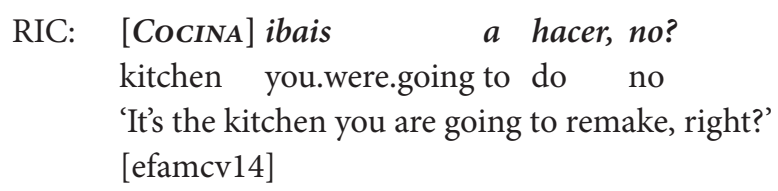

In the Italian example in (32), the conversation takes place one more time at the goldsmith's atelier and AND (the goldsmith) is describing to a worker how the jewel has to be cut. AND wants to point out that the faceting on the jewel does not have to be on the entire surface but that the lower part has to be smooth. DOM's utterance is for DOM to check whether he understood correctly. More precisely, DOM asks for confirmation about the place where the faceting has to be done. The implicit question then is 'Where does the faceting have to be done?'.

(32) Italian

AND: Poi qui, non liscio, ad esempio: qui una limata, una sfaccettatura, come questa [...] qui, una limata, cioè: partire liscio...

'Then here, not smooth; for instance: here you file it, you make a facet, like this one [...] here, a filing, that is: starting smooth...'

DOM: Ah, [solosul BAsso] inizianoad esserci le

ah only on.the low start to be.there the sfaccettature?

facets

'Ah, so it's only in the lower part that the faceting begins?'

[ifamcv28]

In his analysis of fronted focus constructions in Serbo-Croatian, Albanian and Modern Greek, Matić (2003) proposes that in the majority of cases focus evokes a binary set of alternatives. He also argues that certain phrases such as quantifying phrases, sentence adverbials of polarity, 'only'-phrases, given their intrinsic meaning, trigger a binary set of alternatives when focused. A confirmation yes/no question is another case where, for Matić, focus is inherently binary: the two alternatives are the sentence with fronted focus, and its counterpart with opposite polarity. If Matic was right, then the antecedent of the fronted focus would not be a wh-question but rather the proposition with opposite polarity. I argue instead that when a yes/no question has a narrow focus, the speaker does not simply want to know whether his assertion or the one with opposite polarity is correct, but also what the value of the focus is in case his assertion is not correct. In other words, what the speaker is really doing is asking an implicit wh-question and at the same time trying to guess a possible answer. As for the other cases that Matic mentions, I only consider sentences with focus on the polarity as truly binary. They will be discussed in Section 4.5 . 


\section{Types of fronted foci}

In the corpus data I have collected, fronted foci tend to be linguistic expressions with certain characteristics. A classification of the expressions preferably occurring in a fronted position is presented below. I follow rather closely the classification done by Matić (2003) for his study of fronted foci in Serbo-Croatian, Albanian and Modern Greek, although my classification is shorter and less detailed. ${ }^{12}$ Also, I have added point e., which is not present in Matićs list. Fronted foci with additive particles are in fact largely present in my data (as already observed in Brunetti 2008).

(33) a. Quantified expressions

b. Predicatives of qualification

c. Demonstrative pronouns

d. Focal expressions associated with 'only' and 'just/precisely'

e. Focal expressions associated with 'also/even/not even'

The presence of the linguistic expressions listed in (33) will be explained on the basis of the pragmatic functions of fronted foci (contrast/correction, unexpected information, answering a question).

\subsection{Quantified expressions}

Eight cases of fronted quantifiers are present in Italian and two in Spanish. The two Spanish sentences have a particular chiasmus structure and will be discussed apart (Section 4.1.1).

Italian quantifiers are tutti 'all' and nessuno 'nobody', and six out of the eight examples are subjects. We can assume that in Italian and Spanish, despite the freedom of word order which characterizes these languages, subjects tend to stay in a preverbal position whenever possible. However, a preverbal subject position is interpreted, in most contexts, as a topic position (see beginning of Section 2). Considering that nonreferential expressions such as 'all' and 'nobody' are not possible topics, it could be the case that quantified subjects are more acceptable in a preverbal position because they cannot possibly be mistaken for topics. ${ }^{13}$

12. Matićs corpus is very different from mine, both from a quantitative and a qualitative point of view. It is a very large written corpus (about 15,000 clauses per language), whose sources are daily journals, ladies' and teenagers' magazines, samples of narrative prose writing, and three translations of the same English novel. Despite this diversity, the similarity with my data is striking, so the classification is also useful to describe my data.

13. See Endriss (2006) for an account of the restrictions on different types of quantifiers as topics. 
More generally, I propose that focused quantifiers that express an extreme value in a scale of quantities, such as 'all' and 'nobody', are frequently fronted because they provide unexpected information. The alternative set introduced when the focus is a quantifier is a set of quantities. For instance, focus on 'all' introduces an alternative set of the type \{all, some, few, one, etc.\}. When the antecedent is not given in thediscourse, the listener looks for an antecedent in the interlocutors' shared knowledge. The antecedent is a quantity that is expected, because it is part of the shared knowledge. If the fronted focus is 'all' or 'nobody', the quantity will be (respectively) lower and higher in a scale of quantities than the extreme value expressed by the focus, and that extreme value is unexpected with respect to the quantity assumed by the interlocutors as antecedent. ${ }^{14}$

Some examples are given below. In the Italian one in (34), the speaker says that his professor of physics was very good. He also says that the professor used to give very low grades. Then he states with a fronted focus sentence that none of the students were against him. Such a statement is unexpected, because students usually dislike professors who give low grades. So the implicit assumption at the moment of the utterance, shared by the interlocutors considering their knowledge of the world, is that all or at least some students were against the professor. What is particularly unexpected is the fact that among the students none - that is, the smallest possible amount in a scale of quantities - was against the professor.

(34) Italian

a. Io ho avuto un professore bravissimo di fisica [...] e lui era veramente bravo [...] e infatti, nonostante la bassezza dei voti che metteva [...]

'I had a very good physics professor [...] and he was really good [...] and in fact, despite his low grades [...]'

b. [NESSUNo] ce l' aveva con lui

nobody CL it.CL had with him

'NOBODY had it in for that.'

[ifamcv23]

In the Italian example in (35), the speaker is contrasting a shared belief that men usually hook up with young, pretty women. Cuban men, the speaker says, try to hook up with women of any kind. The antecedent is not explicitly given in the discourse, but is clearly recoverable from the interlocutors' shared knowledge of the world, and it is also hinted at by what the speaker says before, namely that Cuban men try to hook up with foreign middle-aged women. Note that loro 'they' is not part of the focus, but is a pre-focal left dislocated subject.

14. On the fact that the alternatives to these fronted foci are ordered in a degree scale, see also Matić (2003:288-289). 
(35) Italian

a. Cosi fanno gli omini cubani con le signore italiane.

'And so do Cuban men with Italian ladies.'

b. [...] le straniere d'una certa età, che le vanno li; 'middle age foreigners who go there;'

c. loro [con TUTTI] provano, capito. they with everybody try understood 'They try (to hook up) with ANYBODY, you know. [ifamdl16]

The Italian example in (36) is taken from a meeting of the city council. The speaker is a council member who is inviting the other members to vote against a certain proposition. He first uses an impersonal construction (bisogna votar contrario 'it is necessary to vote against'), and then he makes clear that he does not mean that only his party members have to vote against, but rather that everybody has to, as the proposition is bad not just from the point of view of his political views, but from any perspective. With the fronted focus sentence the speaker intends to contrast a potential implicit belief that he was only speaking for his party members. By saying that his invitation to vote against is not a matter of political partiality (36b), the speaker suggests that he is contrasting that potential implicit belief, which constitutes the antecedent for the focus variable in (36c).

(36) Italian
a. Io penso bisogna votar contrario, a questo punto;
I think it.is.necessary to-vote against at this point
b. ma ma non è una questione di politica, di colore, eh? but but not is a matter of politics of color
c. [Tutti QUANTI] dobbiamovotar contrario. all so.many we.must to.vote gainst

'I think we have to vote against, at this point; but it's not a matter of political color, you see? EvERYBODy has to vote against.' [ipubcv04]

Quantifiers may also be used in contrastive contexts. An example is (37). The fronted focus sentence has a contrasting alternative in the discourse, when MIC says: 'I have to impose my ideas'. In particular, the subject ognuno 'everybody' is in contrast with io 'I', namely, the speaker challenges the interlocutor's statement by saying that it is not him alone who wants to impose his ideas, but everybody.

(37) Italian

MIC: E chiaro, perché io devo imporre le mie idee [...] se credo nelle mie idee.

'Of course, as I have to impose my ideas [...] if I believe in my ideas.' 


\section{MAR: [Ognuno] vuole imporre le sue idee, però... each.one wants to.impose the his ideas but 'ANYONE wants to impose their own ideas, but...' [ifamdl01]}

Matić (2003) also gives examples of comparative and metaphorical quantification, such as 'like a thunder', 'in waves' etc, of which I have not found any in my corpus. We must note that even in Matić's corpus these fronted foci occur only in Modern Greek, and this language appears to have a syntactically fossilized fronted focus construction, which therefore occurs in a larger set of contexts than Albanian and Serbo-Croatian, where the construction is pragmatically, not syntactically motivated. Italian and Spanish behave more like Albanian and Serbo-Croatian than Modern Greek.

\subsubsection{Chiasmus constructions}

The two fronted quantifiers that I have found in the Spanish data are inserted in special constructions that deserve some attention. The examples are reported below. The quantifiers are un poco de todo 'a little bit of everything' and todo el mundo 'everybody'.

(38) Spanish

Fuimos [...] a despedirnos y eso, y ya nos vinimos; pero bueno, no sé, nos cundió bastante, la verdad, porque... para ir un día y medio, vimos a todo el mundo, [a todo el MUNDo] vimos.

'We went [...] to say goodbye and all, and then we left; but well, I don't know, we actually did a lot, as... in just a day and a half, we saw everybody, EVERYBODY we saw'

[efamcr05]

(39) Spanish

ANT: [...] ahí están los mejores traductores o... [...] o simplemente es una clase especializada?

'Is it the case that the best translators are there, or it is simply a specialized class?'

OLG: Pues, hay un poco de todo, eh?

[Un poco de TODo] empieza a haber.

a little of everything it.starts to have

'Well, there's a little bit of everything, you know? It's a little bit of everything that we are starting to have.'

[epubdl11]

In both cases, the fronted focus sentence is preceded by a canonical sentence with the same meaning. In (38), the two sentences (vimos a todo el mundo and a todo el mundo vimos) are identical except for their word order. In (39), the background of the fronted 
focus sentence is slightly more informative than the background of the canonical sentence (instead of hay 'there is', the speaker says empieza a haber 'is starting to be').

This chiasmus construction has also been observed for French by Abeillé, Godard \& Sabio (2008), who report the following example from a spontaneous speech corpus:

(40) French

a. Mon père il va miacheter un petit mouton. my father he goes to-me.CL to-buy a little sheep

b. [Un petit mouton] il va macheter. a little sheep he goes to.me.CL to.buy

'My father is going to buy me a little lamb; a little LAмв he's going to buy me.'

[Corpaix: Agenet, Gr3,6]

These scholars use the construction as evidence that the fronted element is not focused, because it is not informative in the discourse. I propose, on the contrary, that it is precisely the fact that the two sentences have two different information structures which legitimates the repetition. The former is an all-focus sentence, and the latter is a focus-background sentence. The focus-background sentence indicates that the speaker intends to highlight one part of the previous statement by uttering it again as focus. Since a fronted focus does not need the context to be recognized, that part is interpreted as focus even against the expectations created by the context (in this case, the full-focus sentence). Re-focussing that part makes the listener infer that the information provided by it is particularly important with respect to the rest of the sentence. The reason of its importance may be that the focus value goes against implicitly assumed expectations. For instance, in (38) the antecedent of the focus variable could be the implicit assumption that the speaker and her friends saw few people, because the speaker says that they did not spend much time in that place.

Finally in (39), the repetition of the sentence is further justified by the fact that the background is slightly different. The sentence does not just say that there is a little bit of everything, but that there starts to be a little bit of everything. In order to highlight the phrase un poco de todo, the speaker could have just uttered it again, without the post-focal background. The function of the background here resembles one of the functions of Clitic Right Dislocation: it provides some additional attributive meaning that is not present in its antecedent (cf. Ziv \& Grosz 1998 for English and Mayol 2002 and Villalba 2007 for Catalan). ${ }^{15}$ In (39), the speaker provides additional information concerning the status of the event, namely the fact that it is in its initial state.

15. For instance in (i), the referent of 'my dog' is recovered by the right dislocated epithet the mangy old beast:

(i) a. Itook my dog to the vet yesterday.

b. He is getting unaffordable, the mangy old beast. 


\subsubsection{Further scalar effects}

Further examples in the corpus, although not quantifiers, are worth mentioning at this point because they display, as quantifiers do as well, the effect of introducing a measure which represents the extreme of a scale. In (41), the fronted focus is the temporal expression domattina 'tomorrow morning'.

(41) Italian

[Domattina], se mi rendo conto che... che non è giusto, ciò̀, ci tomorrow if REFL I.realize that that not is right that.is of.it.CL ripenso.

I.rethink

'Right AWAY, if I realize that I'm wrong, I'll give it a rethink'. [ipubcv01]

The speaker is arguing with her interlocutor, and she strongly disagrees with him, but she wants him to know that she has no prejudice against his opinions. She says that if she realizes that she is wrong, she is ready to change her mind 'the morning after', where the morning after is considered as a very short time, basically meaning 'immediately' The speaker contrasts her utterance with an implicit belief shared by the interlocutors that people are unwilling to change their minds and don't do so immediately, and that the morning after is an exceptionally short time to change one's mind, in a scale of possible times. By uttering (41), the speaker wants to emphasize the fact that she has no problem admitting she is wrong, if this turns out to be the case.

In the Spanish example (42), the fronted focus is a prepositional phrase indicating a time: a las nueve y media 'at nine thirty'.

(42) Spanish

a. [...] estuvimos un rato y nos fuimos, porque [...] nos queríamos levantar a las ocho o las nueve para venirnos...

'We stayed a little and then we left, because we wanted to get up at eight or nine to leave...'

b. [a las nueve y MEDIA] nos levantamos al final.

'at half past NINE we got up, in the end.'

[efamcv05]

PAT's discourse preceding the fronted focus sentence is all about her vain attempt to have her friends get up approximately at eight oclock. PAT says that her insistence on having everybody get up early did not bear any fruit and she concludes that they eventually (only) managed to get up at nine thirty. The fact that they got up at nine thirty is unexpected, given the expectations generated by the previous discourse. 'Nine thirty'

See Brunetti (2006, submitted) for an explicit parallelism between the discourse function of right dislocation and that of the post-focal background in fronted focus constructions. 
is considered by the speaker as a high value in a scale of times in which these people could have got up in the given circumstances. ${ }^{16}$

\subsection{Predicatives of qualification}

A small group of fronted elements with partly similar characteristics and functions as the group of quantifiers is that of predicatives of qualification. In Matićs corpus they usually indicate a subjective judgment. This is also the case of the examples reported in (43) and (44), which are copula sentences with a nominal predicative. In (43), the speaker is quoting a character in the story who is negatively judging the frog's behavior. The character says that the frog is made of stone, meaning that he is very insensitive.

(43) Italian

Ma che cuore ha? Un cuore di pietra, [una rana di PIETRA], sei. but what heart has a heart of stone a frog of stone ou.are 'But what a heart does he have? That's a heart made of stone, you are a frog made of stone!'

[iNoc Caterina]

In (44), the speaker is making an ironic comment about the tendency of RIC to always be in a hurry and short of time, calling him 'the timeless man'.

(44) Spanish

RIC: Es que no tengo tiempo, tengo otras cosas que hacer, y siempre lo voy dejando...

'The problem is that I have no time, I have other things to do, and I always postpone it...'

TER: [El hombre sin TIEMPo] es.

the man without time is

'He is the timeless man.'

[efamcr14]

These two subjective comments can be considered as cases of unexpected information. The implicit antecedent is a less strong qualification than the one attributed by the speaker to the frog in (43) and to RIC in (44), which are in fact hyperbolic statements. The listener assumes that the sentence is uttered as in contrast with the weaker statement. In addition to this explanation, I suggest that the characteristics of the post-focal material favor the fronting as well. When a nominal predicative is fronted, the material that follows the focus is just the copula verb. As I already observed above, a copula is semantically light and therefore more easily recoverable than a richer

16. This is a case where the previous discourse contains a shared belief among the interlocutors. See Footnote 10. 
background. Finally, in (43), it is possible that the sequence of linguistic expressions which are uttered by the speaker favors focus fronting. The speaker first asks a rhetorical question (Ma che cuore ha? 'What a heart does he have?'), answered by the fragment un cuore di pietra 'a heart made of stone.' The fragment is then followed by the fronted focus sentence Una rana di PIETRA sei 'A frog made of sTONE, you are. The speaker seems to correct herself by changing 'a heart made of stone' into 'a frog made of stone. Then, in order to give the new expression a grammatical role, she adds the copula verb post-focally.

The two Spanish examples below are copula sentences with an adjectival predicative. In (45), the fronted focus is the adjective contaditos, which means 'scarce', 'limited in number'. The speaker's point is that polite schoolchildren are extremely rare, rarer than one might expect.

(45) Spanish

a. y hay mucho problema con eso; yo los míos son grandecitos, pero educación no tienen ninguna;

'and there are many problems because of that; mine are rather old, but still, they have no manners at all'

b. [CONTADitos] los tienes con educación: siete por clase... few them.CL you.have with manners seven per class

'There are really few who behave: seven per class...' [efamdl15]

Note here that the subjective comment is a quantity: the speaker thinks that there are extremely few polite pupils in each class. The antecedent to this quantity will be a more expected (in this case, higher) quantity in a scale, analogous to what we have seen above for quantifiers. On the other hand, (46) is an example of contrast. The interlocutors are talking about a logo that $\mathrm{CHI}$ is creating. Earlier on in the conversation, NEN had asked CHI why he colored the logo yellow. CHI replies that the color is orange, and NEN insists that it is dark yellow. So NEN is contrasting CHI's claim that the logo is orange. Note that eso 'that' at the beginning of NEN's utterance is not part of the focus, but rather a pre-focal (left-dislocated) subject.

(46) Spanish

CHI: Este es naranja, ¿qué amarillo? ¿Dónde has sacado tú el amarillo?

'This is orange, what yellow are you talking about! Where did you see yellow?'

NEN: Eso [amarillo oscuRo] es, esto no es naranja.

that yellow dark is this not is orange

'That is dark yellow, not orange.'

[efamcv08] 


\subsection{Demonstrative pronouns}

Six fronted demonstratives are present in the Italian corpus (of which four are subjects), and seven in the Spanish corpus (of which three are subjects). While in Italian I found examples with quello 'that', questo 'this', and the dialectal (Tuscan) deictic costi 'there' (denoting a place close to the listener and far from the speaker), in Spanish I only found cases with eso, 'that' (denoting a referent close to the listener and far from the speaker).

The presence of demonstrative pronouns can be explained as follows. We have seen that a fronted focus is used in contexts where the referent of the focus is already known, as shown clearly by the chiasmus constructions in (38) and (39). The strategy there was to first introduce the referent of the focus, and then to focus it again and front it in a subsequent sentence. Just like with demonstratives, the speaker first introduces the referent, and then uses the fronted focus device just to highlight the referent again, but instead of repeating the whole phrase she uses a demonstrative pronoun.

Two examples of demonstrative fronted foci are (2) and (21). Another example is (47) below. The conversation is about the fact that PAT and MIG have just bought an apartment. With her first utterance, ROS intends to emphasize the fact that her friends will soon be owners of an apartment. PAT's reply mitigates ROS's enthusiasm with ironic words that are made clearer by MIG's subsequent statement. PAT and MIG's point is that they won't be owners until they pay the entire mortgage, which will take a long time.

(47) Spanish

ROS: ¡Jo! y luego ya vais a ser propietarios, ahí.

'Wow! And then you are going to be owners, there.'

PAT: Sí, propietarios de una mierda.

yes owners of a shit

'Sure! Owners of a shit!'

ROS: hhh

PAT: [De Eso] vamos a ser propietarios.

of that we.are.going to be owners

'That's what we are going to be owners of!'

MIG: Propietarios de una hipoteca.

'Owners of a mortgage.'

[efamcv01]

PAT first introduces the referent which she intends to contrast with the apartment (a shit). Then she utters a fronted focus sentence with the same referent, represented by a demonstrative pronoun. The fronted focus does not identify that referent again, but is left with the sole function of contrasting it with an alternative referent in the discourse. 
Matić notes that another context in which a demonstrative occurs is when the fronted focus sentence expresses a conclusive note to prior discourse. In my data, this case is exemplified by (48) (Spanish), where ese 'that one' refers to what the speaker has said in (48a), namely that Raquel does not realize what a stupid person her friend is.

(48) Spanish

a. Pero el problema es que Raquel no es consciente de que ella es una gilipollas.

'But the problem is that Raquel is not aware that she is a jerk.'

b. [ESE] yo creo que es el problema.

that I think that is the problem

'THAт is the problem, I think.'

[efamdl04]

The antecedent is not given in previous discourse, but is simply inferable as a conclusive statement that summarizes the previous discourse. The antecedent can, for instance, be interpreted as an implicit question ('What is the problem?'). ${ }^{17}$ The interlocutors' previous conversation was in fact an attempt to understand the negative aspects of the fact that their friends are going on a trip with a particularly annoying person. The negative aspect - the problem - is what the speaker says in (48a), and is referred to in (48b) by the demonstrative.

\subsection{Focus sensitive particles}

Matić (2003) says that in the three languages in his corpus, the focus sensitive particles 'only' and 'just/precisely' are often associated with a fronted focus. The same is true for Italian but not for Spanish, at least in my data. In this language, the only focus particles associated with the six fronted foci found are additive particles (también 'also', hasta 'even') or their negative counterpart (tampoco). In Italian, additive particles like anche, pure 'also', persino 'even', or their negative counterparts (neanche, nemmeno, neppure) are also very common. In effect, they are more frequent than the other particles. Out of 29 fronted foci associated with a focus sensitive particle, 24 are associated with additive ones. The expression associated with the particle is mostly the subject ( 23 cases), so the word order is not marked; only the position of the focal accent is. In Spanish, four of the six fronted foci are subjects. The large presence of subjects might be due to the following reason. A preverbal subject in a sentence with a normal intonation is interpreted as the topic of a topic-comment structure. In order to be focused, it has to be placed in a post-verbal position (cf. Pinto 1997; Belletti 2001,

17. Within a model of discourse such as the one proposed by Roberts (1996), an implicit question summarizing the previous discourse would be the most general (hierarchically, the topmost) 'question under discussion' among those that form the structure of that discourse segment. 
among others). However, the argument that is adjacent to a focus particle is expected to be focused, so a subject associated with a focus particle may stay in its canonical preverbal position without the risk of being interpreted as a topic. The presence of the particle favors a focus interpretation of the subject, despite its preverbal position.

Focus particles trigger a presupposition that there is (or there is not) an alternative value for which the proposition holds. More precisely, additive particles imply that there is an alternative value for which the proposition holds (cf. König 1991, among others). 'Only' and other restrictive particles imply that there is no alternative value for which the proposition holds (cf. Roberts, submitted). The antecedent of the variable introduced by a focus is constrained by the semantics of the particle. When a fronted focus is associated with an additive particle, the context must provide an antecedent stating that the proposition applies to some other entity (49a). In the case of restrictive particles, the context must provide an antecedent stating that the proposition applies to both the entity expressed by the focus and another entity (49b).

(49) Italian

a. [Anche a MARIA] ho svelato il segreto. also to Maria I.have revealed the secret 'I also told the secret to Maria.'

a. Antecedent: I revealed the secret to someone differerent from Maria.

b. [Solo a MARIA] ho svelato il segreto. only to Maria I.have revealed the secret 'I only told the secret to Maria.'

b. Antecedent: I revealed the secret to Maria and to someone different from Maria.

Focus particles in Italian and Spanish are adjacent and precede the focus (unless the focus is fronted, in which case certain particles can follow it), so the particle delimits the focus phrase to the left. Therefore, even if the focus is low, the sentence cannot be interpreted as fully focused, as the particle blocks projection of the focus further up. This means that the extension of the focus is not ambiguous, as in the other cases seen above. However, note that - like in normal cases of contrast and unlike question-answer pairs where the extension of the focus is immediately predictable from the question (when the question is explicit and salient) - the context does not help predicting what the focus will be in a subsequent sentence and whether it will be associated with a focus particle. Even if the context provides an antecedent and the listener can predict the extension of the focus, he can hardly predict the restrictions on the antecedent imposed by the particle until the particle is uttered. For this reason, fronting with focus particles occurs in the great majority of contexts. ${ }^{18}$

18. The anonymous reviewer argues that the syntactic position of elements associated with focus particles is different from that of a fronted focus, at least from what we see in some languages (e.g. Hungarian). This can be true, given that focus particles trigger a presupposition that is 
Some examples are given below. Consider the Italian one in (50). The additive particle anche is associated with the focus la donna 'the woman'. The implication triggered by the particle is that someone other than the woman felt like eating. The listener can infer from the context that such an individual is the frog, as the speaker says that the frog decides to go into the picnic basket (where supposedly food is stored).

(50) Italian

a. La rana decide di entrare nel cestino. [...] the frog decides to enter in-the basket

b. E contemporaneamente [anche la DONNA] aveva voglia di and at.the.same.time also the woman had desire to mangiare un poco.

eat a little

'The frog decides to go into the basket, and at the same time, the woman too felt like eating a little.'

[iNoc Caterina]

In (51), the additive particle pure (which can either precede or follow the focus) is associated with il gatto 'the cat'. The implication triggered by the particle is that someone other than the cat is interested in the bottle. That individual is clearly the frog, of which the speaker had said before that it had grasped the bottle (cf. (51a)).

(51) Italian

a. Però la rana è [...] un po' più veloce, e zacata! Si prende il biberon.

'But the frog is a little faster and zac! She grabs the bottle.'

b. [Il gatto PURE] è un po' interessato al biberon. the cat too is a little interested at.the bottle 'Even the cat has some interest in the bottle.'

[iNoc Andrea]

In the Spanish example in (52), the focus is associated with the particle tampoco 'not even', which can either precede or follow the focus. When it follows it, it bears main prominence. The focus expression is ahi 'there', and it contrasts with other places mentioned in the story from which the frog had been sent away. The implication triggered by the particle is that the frog is not loved in other places. The listener can infer it by the fact that the frog had to leave the other places.

more constrained than that triggered by the focus alone. My analysis, however, is not affected. In fact, when the focused element is fronted, sentences with focus-sensitive particles share with the other fronted focus sentences the fact that they display a focus-background structure, and the consequences of having such a structure are the same. 
(52) Spanish

Bueno pues que la rana se tiene que volver a ir, y [ahí TAMPoco] la quieren.

'So well the frog has to leave again, neither is she loved there.'

[eNoc Carmen]

Another Spanish example is (53). The particle is hasta 'even', which always precedes the focus, so the focus is los propios chinos 'the very Chinese people', and the accent falls on chinos. Hasta triggers the implication that the proposition holds for some values and that it is more likely that the property holds for such values than for the value expressed by the fronted focus. In (53), the implication is that non-Chinese people usually give the English name 'Beijing' to the capital of China. This can be inferred from what PAS says in the preceding exchange.

(53) Spanish

ANA: Sí, es que allí todo el mundo habla de Shanjai.

'Yes, because everybody there says 'Shanjai".

PAS: [...] con la manía de Beiking en lugar de Pekín 'and the mania of saying 'Beiking' instead of 'Pekin"

ANA: Es que allí [hastalos propios cHINos] muchas veces is that there even the very Chinese many times dicen 'Beijing',

say 'Beijing'

'The point is that even Chinese people themselves often say 'Beijing.' [efamcv04]

In the Italian example in (54), which is a part of a conversation between two siblings and their mother, ANT (the sister) says that MIC (the brother) is overconfident. Then the mother says that overconfidence is a hereditary fact, meaning that it is a common aspect of all members of the family. This statement invites MIC to claim that his sister is overconfident, too. The implication triggered by the particle is that there are other people who are confident apart from ANT. This implication can be inferred from ANT's first utterance (lui è troppo presuntuoso...) or from what the mother says, namely that everybody in the family is overconfident.

(54) Italian

ANT: E poi lui è troppo presuntuoso perché io ci lasci stare...

'And he is too overconfident for me to let it go...'

MAR: Va bene, in quanto alla presunzione, è un fatto ereditario di famiglia.

MIC: Si.

'Well, as for overconfidence, it's a hereditary fact.'

'It is.'

ANT: Eh, purtroppo, si.

'Eh, unfortunately it is.' 
MIC: [Anche LEI] è presuntuosa, anche LEI è presuntuosa. also she is overconfident also she is overconfident 'She too is overconfident, she too is overconfident.' [ifamdlo1]

The Italian example in (55) is the only example with 'even' (perfino). The speaker says that everybody was very happy, and then specifies that even the frog was happy. Since the frog is unlikely to be happy in those circumstances (the little frog she was jealous of has come back after being lost for some time), tutti 'all' in the first utterance may be interpreted by the listener as all but the frog. So the speaker feels obliged to explain that the frog is included in the set of happy people. The implication triggered by the particle is that there are other people who are happy and that these people are more likely to be happy than the frog. The first utterance in (55) clearly allows the listener to make such an inference.

(55) Italian

Erano tutti contentissimi. Eh sì, [perfino la RANA] era contenta.

'They were all happy. Yes, even the frog was happy'.

[iNoc Caterina]

Finally, in (56), the focus is associated with the restrictive particle soltanto 'only'. The speaker and her interlocutor are talking about certain changes that could be made to a law that regulates TV advertising in Italy if a proposal submitted for popular vote passed. The speaker explains that one change provides that the advertisements during a film on TV will be prohibited, except for the time slot between the first and the second half of the film. The speaker argues that this will make that single time slot more expensive than it is now, so only a few advertising agencies (the bigger and more powerful ones) would be able to buy a part of it.

(56) Italian

a. [...] se lo spazio tra il primo e il secondo tempo [...] costa di piu

'[...] if the slot between the first and the second part [...] costs more'

b. perché non puoi... a questo punto è uno solo

'because you cannot... at that point there's just one'

c. per cui [soltanto poche PUBвLICITÀ] possono comprarsi quello spazio li.

'then only few advertising agencies can buy that one slot.'

[ifamdl13]

Since soltanto associates with poche pubblicità 'few advertising agencies', the implication triggered by the particle is that all, or many, advertising agencies will be able to buy a part of it. The implication can be inferred from the fact that the whole conversation was about the idea that the law aims at making life easier for all (even small) agencies. 


\subsection{Polarity focus}

Leonetti \& Escandell-Vidal (this volume) present another type of fronting in Spanish (existing also in Italian), which they call Verum Focus Fronting. The main formal difference with focus fronting is the fact that the fronted element does not bear the nuclear accent. In fact, according to Leonetti \& Escandell-Vidal's proposal, the fronted element is not focused: the fronting is a strategy to unambiguously identify the focus on the polarity of the sentence by eliminating the possibility to interpret the sentence as a topic-comment or a focus-background structure. Assuming as they do that focus on the polarity is a particular case of narrow focus (cf. Féry 2007), a verum focus fronting construction does in fact have, just like a focus fronting construction, a focus part and a background part: the polarity is the focus and the whole sentence is the background. However, unlike focus fronting, the focus-background partition is not lineally represented in the sentence. As Leonetti and Escandell-Vidal observe, a transparent representation of the focus-background order when focus is on the polarity is given by sentences introduced by Spanish sí que 'yes that'. The focus is sí, representing the polarity, and the background is the entire sentence which comes after it. I found 48 of these constructions in the Spanish corpus. Sì che 'yes that' constructions exist in Italian as well, but none was found in the corpus, so this strategy is clearly not exploited in the same way as it is in Spanish. The difference is striking because Italian and Spanish share all other polarity focus constructions: focus on the auxiliary or on the verb, expressions like 'it is true that', and verum focus fronting. ${ }^{19}$ Two examples of sí que constructions are given below.

(57) Spanish

OLG: a. Porque una novela no me apetece traducir,

'Because I don't like to translate a novel'

b. pero sí que me apetece traducir un...

but yes that to.me.CL appeals to-translate a ...

'but I do like to translate a...'

ANT: ... un libro de lo que sea.

'... a book of no matter what.'

[epubdl11]

(58) Spanish

ANT: Y eso cómo se repercute en la factura del traductor? [...]

'And how does this affect the translator's salary?'

OLG: [...] normalmente lo que ocurre es que al mal traductor [...] no se le vuelve a llamar [...];

al que eh no es demasiado malo [...]

19. Matić (2003) also presents cases of fronted adverbials denoting the polarity of the sentence, such as 'really', 'without doubt', 'with certainty', etc. There weren't any of such expressions in my corpus, neither in Spanish nor in Italian. 


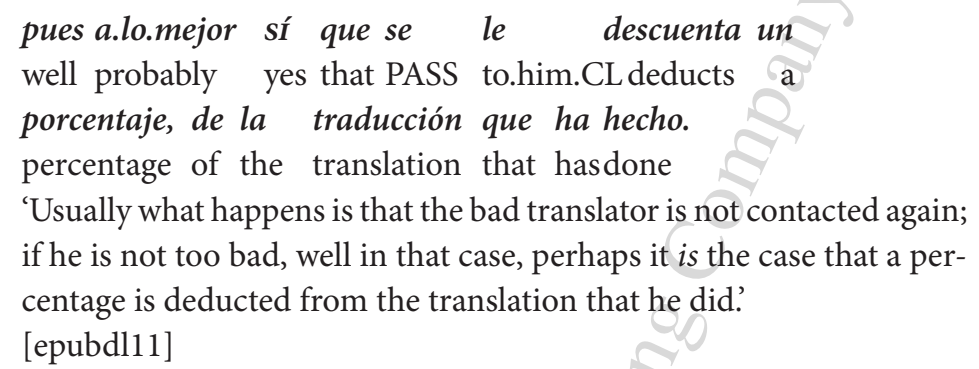

The focus semantic value of a sentence with a polarity focus is made of two alternatives: the positive and the negative form of the sentence. Since there are just two alternatives, the antecedent is automatically retrievable from the focus value: it is the remaining alternative of the set. Given that the characteristics of the antecedent are already known, the link between it and the context can be looser. The examples above show that. Consider (57): The speaker - a translator - says that she does not like to translate novels. Then she says that she does like to translate a book about no matter what. The antecedent for the focus variable (the positive polarity) cannot be but the negative polarity (that she does not like to translate a book). The negative proposition is implicitly recoverable from the fact that the speaker has said that she does not like to translate novels. The listener can infer that the speaker does not like to translate books in general, and the si que sentence contradicts that inference. Since the listener knows what the antecedent has to look like, the inference is easy to make. In (58), the antecedent with opposite polarity (the assertion that the translator's salary is not reduced) is inferable from the context in the following way. OLG first answers ANT's question by saying that the translator is usually not contacted again if he has done a bad job. So OLG implies a negative answer to ANT's question: it is not the case that the translator's salary is reduced. Then OLG additionally says, by means of the si que construction, that translators who are not too bad may indeed see their salary reduced. OLG's statement then contrasts with her previous implicit answer to ANT's question.

\section{Conclusions}

In this paper I have analyzed the discourse functions of fronted foci in Italian and Spanish. Within an Alternative Semantics framework (Rooth 1992), I have assumed that the antecedent of the variable introduced by the focus is determined pragmatically, and I have analyzed the pragmatic strategies to determine the antecedent in sentences with a fronted focus. I have argued that a fronted focus is unambiguously identifiable, so its antecedent is recoverable even if not explicitly present in the discourse context. This favors the use of fronted focus in contrastive/corrective contexts, in contexts where the information is felt to be unexpected, and in contexts where the sentence answers an implicit or not salient question. In contrastive contexts, a fronted focus is used to help the listener understand that the sentence is uttered in contrast 
with a previous one and what the contrasting parts are. The fronting preferably occurs when the contrasted proposition is far back in the discourse or is not explicitly given. In fact, the fronting identifies the focus and therefore facilitates the recovering of the antecedent for the focus variable. In contexts where the information is felt to be unexpected, the focus contrasts with an implicit belief shared among the interlocutors, taken from their world knowledge. That belief is recoverable only if the sentence disambiguates the focus. In fact, if the focused element is identified, the listener will search for the right antecedent for it and therefore, in absence of that antecedent in the discourse, she will infer it from the interlocutors' shared knowledge. Finally, the fronted focus is used as an answer to a question when the question is not salient or is only implicitly recoverable. In fact, the extension of the focus of the answer allows the listener to recover the question.

In this paper I have also shown that fronted foci are frequently - although not always - quantified expressions, expressions of predicative qualification, demonstrative pronouns and expressions associated with focus sensitive particles. These characteristics are compatible with the discourse functions of fronted foci described in the paper. Focused quantifiers like 'all', 'nobody' are fronted to provide unexpected information. The antecedent of the quantifier is in fact a quantity shared by the interlocutors, which is lower (or higher) with respect to the extreme value expressed by the quantifier in a scale of quantities. Predicatives of qualification expressing a subjective judgment can also be used to express an extreme value of a scale of judgments. I suggest that their fronting is facilitated by the fact that the post-focal predicate is just the copula and hence semantically light. Focused demonstrative pronouns occur in a fronted position because a speaker may first introduce a referent in a full-focus sentence, and then use the fronted focus just to highlight the referent again for pragmatic purposes. Since the referent is already given, a demonstrative pronoun is used the second time. Furthermore, a fronted focus is used with focus sensitive particles in order for the specific antecedent which the particle requires to be immediately retrieved by the meaning of the particle itself. Sí que polarity sentences in Spanish are finally mentioned because they display an unambiguous focus-background structure, like other fronted focus constructions.

\section{References}

Abeillé, A., Godard, D. \& Sabio, F. 2008. Les constructions avec SN antéposé. Talk presented at the Laboratoire Parole et Langage, Aix-en-Provence.

Belletti, A. 2001. 'Inversion' as focalization. In Subject Inversion in Romance and the Theory of Universal Grammar [Oxford Studies in Comparative Syntax], A. Hulk \& J.-Y. Pollock (eds), 60-90. Oxford: OUP.

Benincà, P., Frison, L. \& Salvi, G. 1988 [2001]. Lordine delle parole e le costruzioni marcate. In Grande grammatica italiana di consultazione, L. Renzi, G. Salvi \& A. Cardinaletti (eds), Vol. 1, 115-225. Bologna: il Mulino. 
Berman, R. A. \& Slobin, D.I. (eds). 1994. Relating Events in Narrative: A Crosslinguistic Developmental Study. Mahwah NJ: Lawrence Erlbaum.

Brunetti, L. 2004. A Unification of Focus. Padova: Unipress.

Brunetti, L. 2006. Italian background: Links, tails, and contrast effects. In Proceedings of the Ninth Symposium on Logic and Language, B. Gyuris et al. (eds), 45-52. Budapest: Research Institute for Linguistics, Hungarian Academy of Sciences, Eötvös Loránd University.

Brunetti, L. 2008. On the pragmatics of post-focal material in Italian (left peripheral focus looked at from the other side). In Les linguistiques du détachement. Actes du colloque de Nancy (7-9 juin 2006) [Sciences pour la communication 87], D. Apothéloz, B. Combettes \& F. Neveu (eds). Bern: Peter Lang.

Brunetti, L. In press. On links and tails in Italian. To appear in Lingua.

Cinque, G. 1993. A null theory of phrase and compound stress. Linguistic Inquiry 24(2):239267.

Cresti, E. \& Moneglia, M. 2005. C-Oral-Rom. Integrated Reference Corpora of Spoken Romance Languages [Studies in Corpus Linguistics 15]. Amsterdam: John Benjamins.

Endriss, C. 2006. Quantificational Topics. A Scopal Treatment of Exceptional Scope Phenomena. Doctoral dissertation, Universität Potsdam.

Féry, C. 2007. Information structural notions and the fallacy of invariant correlates. In The Notions of Information Structure, C. Féry, G. Fanselow \& M. Krifka (eds), 161-184. Potsdam: Universitätsverlag Potsdam.

Geurts, B. \& van der Sandt, R. 2004. Interpreting focus. Theoretical Linguistics 30(1): 1-44.

König, E. 1991. The Meaning of Focus Particles: A Comparative Perspective. London: Routledge.

Matić, D. 2003. Topics, Presuppositions, and Theticity: An Empirical Study of Verb-subject Clauses in Albanian, Greek, and Serbo-Croat. PhD dissertation, Universität zu Köln.

Mayol, L. 2002. "Ho sabieu això?" La dislocació a la dreta en català i anglès. Senior Thesis, Universitat Pompeu Fabra.

Neeleman, A. \& van de Koot, H. 2007. The nature of discourse templates. Ms, University College London.

Pinto, M. 1997. Syntax and Interpretation of Inverted Subjects in Italian. PhD dissertation, OTS, Utrecht University.

Prince, E. 1999. How not to mark topics: 'topicalization' in English and Yiddish. In Texas Linguistics Forum, Ch. 8. Austin TX: University of Texas.

Reinhart, T. 1995. Interface strategies. OTS Working Paper.

Reinhart, T. 2006. Interface Strategies. Optimal and Costly Computations [Linguistic Inquiry Monographs 45]. Cambridge MA: The MIT Press.

Rizzi, L. 1997. The fine structure of the left periphery. In Elements of Grammar: Handbook in Generative Syntax, Haegeman, L. M. (ed.), 281-337. Dordrecht: Kluwer.

Roberts, C. 1996. Information structure in discourse: Towards an integrated formal theory of pragmatics. In Papers in Semantics [OSU Working Papers in Linguistics 49], J.-H. Yoon \& A. Kathol (eds), 91-136. Columbus OH: The Ohio State University Department of Linguistics.

Roberts, C. Submitted. Only, presupposition and implicature. Journal of Semantics.

Rooth, M. 1985. Association with focus. PhD dissertation, University of Massachusetts at Amherst.

Rooth, M. 1992. A theory of focus interpretation. Natural Language Semantics 1(1): 75-116.

Salvi, G. 1988. Italiano: sintassi. In Lexikon der Romanistischen Linguistik, G. Holtus, M. Metzeltin \& C. Schmitt (eds), vol. 4, 112-132. Tübingen: Niemeyer. 
Samek-Lodovici, V. 2006. When right dislocation meets the left-periphery. A unified analysis of Italian non-final focus. Lingua 116(6): 836-873.

Samek-Lodovici, V. This volume. Topic, focus, and background in Italian clauses.

Strömqvist, S. T. \& Verhoven, L. T. (eds). 2004. Relating Events in Narrative. Vol. 2: Typological and Contextual Perspectives. Mahwah NJ: Lawrence Erlbaum.

Vallduví, E. 1992. The Informational Component. New York: Garland.

Vallduví, E. 2002. Information packaging and dialog. Talk presented at EDILOG, Workshop on the semantics and pragmatics of dialogue. September 2002. University of Edinburgh.

Villalba, X. 2007. La dislocació a la dreta en català i castellà, microvariació en la interfície sintaxi/pragmàtica. Caplletra: revista internacional de filología 42: 273-302.

Ziv, Y. \& Grosz, B. 1993. Right dislocation and attentional state. In The Proceedings of the Ninth Annual Conference, Ben Gurion University of the Negev, R. Buchalla \& A. Mittwoch (eds), 184-199. Jerusalem: Akademon.

Zubizarreta, M. L. 1998. Topic, Focus, and Word Order [Linguistic Inquiry Monographs]. Cambridge MA: The MIT Press.

Zubizarreta, M. L. 1999. Las funciones informativas: Tema y foco. In Gramática descriptiva de la lengua española, I. Bosque \& V. Demonte (eds), Vol.3, 4215-4244. Madrid: Espasa Calpe. 


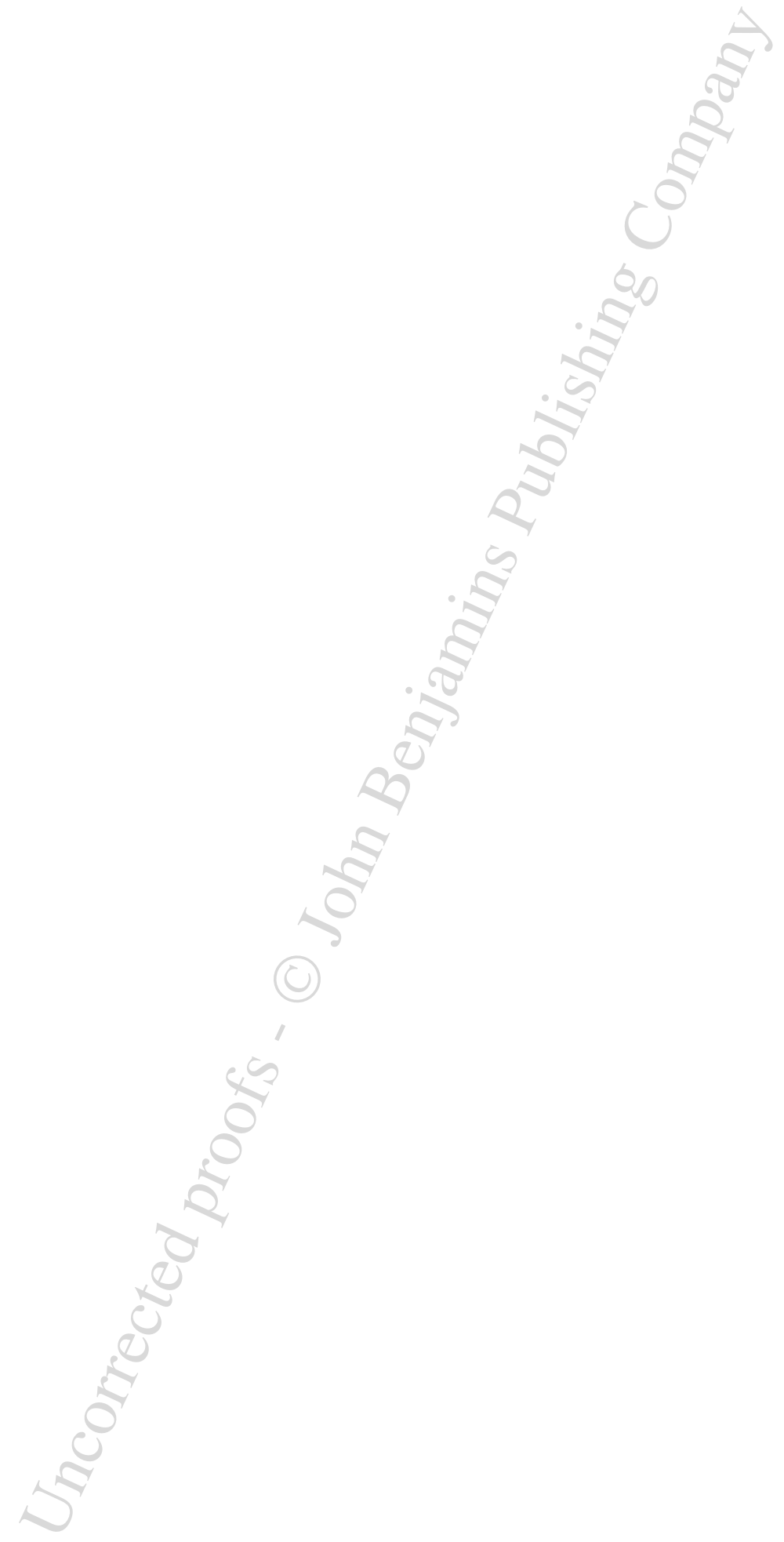

